\title{
Effects of feeding and social factors on diarrhoea and vomiting in infants
}

\author{
J EATON-EVANS AND A E DUGDALE
}

Human Nutrition Research Group, Department of Child Health, University of Queensland, Australia

SUMmaRY In a prospective study of infants and their feeding in south east Queensland, Australia, the incidences of reported diarrhoea and/or vomiting in breast, bottle, and mixed (breast and bottle) fed infants were compared from birth to 1 year. Up to 6 months infants who were given breast feeds, with or without other milks, had less diarrhoea and/or vomiting than those given bottle feeds only. Breast feeding seemed to protect the infant against possible introduced infections even when other milks were given along with the breast milk. After 6 months breast feeding did not reduce the incidence of gastrointestinal infection. In both upper and lower social class families infants given solids before 3 months had less diarrhoea and/or vomiting than those given solids later. Bottle fed infants aged 3-6 months in upper social class families had fewer gastrointestinal problems than those of lower social class families. This study suggests that up to the age of 6 months, in this population, breast feeding protects the infant against diarrhoea and/or vomiting, but other milks and solids can safely be given to supplement the breast milk. Breast feeding conferred no significant protection after 6 months.

Mothers are encouraged to breast feed their infants. ${ }^{1}$ In developed Western countries some studies, ${ }^{2}{ }^{3}$ but not all, ${ }^{+6}$ have shown that the incidence of diarrhoea and/or vomiting $(D / V)$ is lower in breast fed infants compared with those not receiving breast milk. Lower respiratory tract and ear infections are also reduced, ${ }^{278}$ but upper respiratory tract infections are not." In Western countries the trend back to breast feeding has been led by upper and middle social class mothers. ${ }^{10-12}$ Through better environment and hygiene, these upper and middle class families already have lower rates of infection than lower class families. ${ }^{913}$ It is therefore necessary to separate clearly the benefits of breast feeding from those of social class.

Sooner or later, other foods and milks must be given to a breast fed infant. ${ }^{14}$ With such foods comes the risk of bacterial and other infections. ${ }^{15} 16$ Once these foods are introduced, should the mother continue to breast feed and, if so, for how long?

We have studied this problem on a group of Australian mothers and their infants to determine which factors contribute to $\mathrm{D} / \mathrm{V}$ in these infants and the measures that the mothers can take to minimise the risk.

\section{Patients and methods}

Brisbane and Ipswich are subtropical cities in south east Queensland, with populations of 1000000 and 80000 people, respectively. Mothers of infants born in 1984 who attended maternal and child health clinics in four centres in these two cities were asked if they would participate in a one year prospective study on the growth and feeding of their infants. The clinics were selected to cover the range of social classes. Mothers were interviewed for a year at roughly monthly intervals from the time their infants were about 1 month old.

At the first interview the mothers were asked their husbands' occupations and other information about their families. During the first and at each subsequent interview, the mothers were asked if their infants had had any feeding or health problems since the last interview and, if so, what treatment was given and who advised this treatment. Mothers were asked if they were breast, bottle, or mixed (breast and bottle) feeding their infants and if they gave them foods other than milk.

In these analyses the ages of the infants have been divided into $0-3,3-6,6-9$, and 9-12 months. For each of these periods, the infants were included in the results for these months if they continued to 
participate in the study throughout the three month period. Of 173 infants recruited into the study, about $25 \%$ dropped out before the infants were a year old, either in the first two or three months or later because the families moved to another area.

Infants were considered to have diarrhoea and/or vomiting $(\mathrm{D} / \mathrm{V})$ if their mothers, at one of the monthly interviews, said that their infants had required treatment for this problem. The data from each monthly interview were combined into three monthly intervals ( + two weeks). Each infant was counted only once, even though he may have had more than one attack of $\mathrm{D} / \mathrm{V}$ in the three months. Infants were not considered to have $\mathrm{D} / \mathrm{V}$ if they possetted after feeds or if they had $\mathrm{D} / \mathrm{V}$ but their mother took no specific action.

The milk feeds of infants over each three months were recorded as either (1) breast fed only, (2) bottle fed only, (3) mixed (breast and bottle) fed, or (4) weaned, if breast milk was stopped and replaced with bottle feeding in the three month interval. The giving of solids did not affect this classification. Infants were counted as having solids in the preceding months if at any time in that period they were given solids.

The husbands' occupations were used as indicators of social class, using the Congalton Australian classification. ${ }^{17}$ The grades of this classification are professional $=1$, managerial and business $=2$, office and sales $=3$, farmers and technicians $=4$, skilled workers $=5$, semi-skilled workers $=6$, and unskilled workers $=7$. In the analyses social class was divided into upper (grades 1-4) and lower (grades 5-7) social classes. To test the effect of parity, mothers were divided into para 1 and para $2+$.

Data were compared by simple tabulation with the $\chi^{2}$ test or Fisher's exact test and by using a multiway, non-parametric method that separated the effects of the different factors in a multi-factorial situation and tested the independent significance of each factor. ${ }^{18} 19$

\section{Results}

Pattern and treatment of diarrhoea and/or vomiting $(\mathrm{D} / \mathrm{V})$. Altogether, 173 infants were enrolled in the study. Of these, 123 were seen for the full year. Sixty six $(54 \%)$ of these 123 infants had one or more episodes of $\mathrm{D} / \mathrm{V}$ in their first year (Table 1). Most of the $D / V$ was minor. Only three infants were admitted to hospital for $\mathrm{D} / \mathrm{V}$ and none died. These three infants were all less than 6 months old and were either bottle fed or weaned.

The overall patterns of $\mathrm{D} / \mathrm{V}$ related to social class, milk feeding, and age of infant are shown in the Figure. Diarrhoea and/or vomiting was most
Table 1 Numbers of infants with diarrhoea andlor vomiting $(D / V)$ between $0-3,3-6,6-9$, and 9-12 months. The mother's source of treatment was an indication of the severity of $D / V$

\begin{tabular}{lllll}
\hline & \multicolumn{4}{l}{ Age of infant (months) } \\
\cline { 2 - 5 } & $0-3$ & $3-6$ & $6-9$ & $9-12$ \\
\hline Total No of infants & 143 & 137 & 129 & 123 \\
$\begin{array}{l}\text { No of infants with } \\
\text { D/V treated by: }\end{array}$ & & & & \\
Mother & 2 & 5 & 5 & 9 \\
Nurse & 4 & 4 & 0 & 0 \\
Doctor & 11 & 14 & 15 & 25 \\
$\quad$ Hospital & 2 & 1 & 0 & 0 \\
Total No (\%) & & & & \\
$\quad$ with D/V & $19(13)$ & $24(18)$ & $20(16)$ & $34(28)$ \\
\hline
\end{tabular}

Upper social class Lower social class
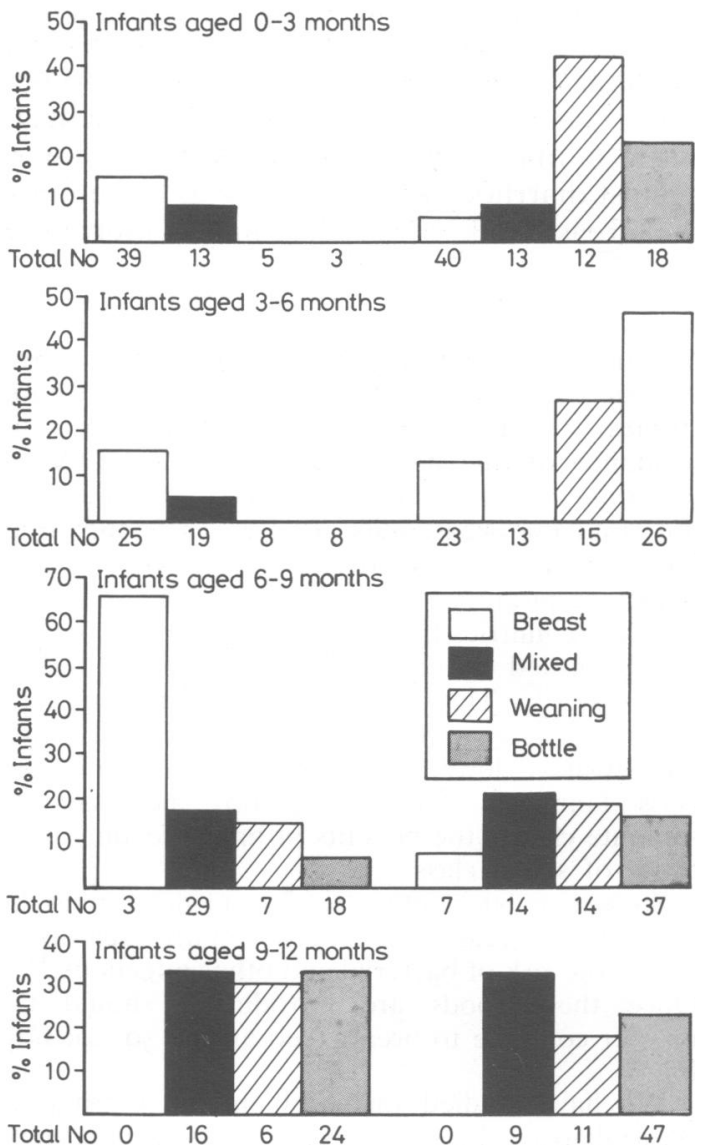

Figure Percentage of infants with diarrhoea and/or vomiting by age of infant, type of milk feed, and social class. 
common in infants aged 9-12 months. The Figure shows that up to 6 months infants from lower social class families generally had more $D / V$ than those from upper social class families. After the age of 6 months the effect of social class disappeared. For infants aged 6-9 months, the incidence of $D / V$ in breast fed infants seems high, but there were only three infants in this group, so the difference in the incidence of $D / V$ with various feeding regimens was not significant.

The type of feeding, social class of the family, and parity of the mother may all affect the incidence of $\mathrm{D} / \mathrm{V}$ in the infant at any age. Multi-factorial analyses were used therefore to isolate the effects of each factor. ${ }^{18} 19$ In the following analyses only infants either breast, bottle, or mixed fed throughout for each three month period have been included (Table 2 ; more detailed tables are available from the authors on request).

Between birth and 3 months, it was found that the proportion of infants with $\mathrm{D} / \mathrm{V}$ did not differ significantly between those who were breast fed and those who were mixed fed (breast $10 \%$, mixed $8 \%$ ), but infants who were bottle fed had significantly more D/V than those mixed fed (bottle $20 \%$, mixed $8 \% ; p=0.03)$. Social class and parity had no effect. Infants given solids before 3 months had less $\mathrm{D} / \mathrm{V}$ than those not given solids (solids $5 \%$, no solids $16 \% ; \mathrm{p}=0.003$ ). This unexpected finding was present separately in upper and lower social classes and for all types of milk feeding. (The percentage incidences given in the text make no allowance for other factors that may influence the incidence of D/V.)

A similar analysis was performed for infants aged 3-6 months. The multi-way median test found no significant differences in the proportion of infants with $\mathrm{D} / \mathrm{V}$ between those who were breast fed and those who were mixed fed (breast $15 \%$, mixed $3 \%$ ), but infants who were bottle fed had significantly more D/V than those who were mixed fed (bottle $35 \%$, mixed $3 \% ; p=0 \cdot 005)$. Overall, the social class of the family had no effect, but among the bottle fed infants those from the lower social classes had more $\mathrm{D} / \mathrm{V}$ than those from the upper social classes (lower social class $4 / 18$, upper social class $0 / 3$; Fisher's exact test, $\mathrm{p}=0 \cdot 01)$. The parity of the mother had no effect (para $117 \%$, para $2+18 \%$ ). Breast fed infants given solids by 6 months had less $D / V$ than those who were not given solids (solids $16 \%$, no solids $50 \%(2 / 4) ; p=0.01)$.

For infants between 6 and 9 months, the overall incidence of $\mathrm{D} / \mathrm{V}$ was $16 \%$. The multi-way median test showed no significant differences in the proportion of infants with $D / V$ when breast fed infants were compared with mixed fed infants or when mixed fed infants were compared with bottle fed infants. Social class of the family and parity of the mother had no effect. All infants received solids by 9 months.

By 1 year all infants received non-breast milks, although some were still breast fed. Between 9 and 12 months the overall incidence of $\mathrm{D} / \mathrm{V}$ was $28 \%$. There were no significant differences in the proportion of infants with $\mathrm{D} / \mathrm{V}$ between the mixed and bottle fed groups. Social class of the family and parity of the mother had no effect.

\section{Discussion}

Under the age of 6 months infants given only formula or cow's milk feeds had significantly more

Table 2 No (\%) of infants with diarrhoea and/or vomiting (D/V) between 0-3, 3-6, 6-9, and 9-12 months by type of milk feeding and giving of solids

\begin{tabular}{|c|c|c|c|c|c|c|c|c|c|}
\hline \multirow{4}{*}{$\begin{array}{l}\text { Infants' } \\
\text { age }\end{array}$} & \multicolumn{9}{|l|}{ Solids } \\
\hline & \multicolumn{4}{|l|}{ Given } & \multicolumn{5}{|c|}{ Not given } \\
\hline & \multicolumn{9}{|c|}{ Milk feed } \\
\hline & Breast & Mixed & Bottle & Subtotal & Breast & Mixed & Bottle & Subtotal & Total \\
\hline $\begin{array}{l}\text { 0-3 months } \\
\text { Total No } \\
\text { No (\%) with } D / V\end{array}$ & ${ }^{23}(0)$ & ${ }^{14}(0)$ & $\begin{array}{l}20 \\
3(15)\end{array}$ & $\begin{array}{l}57 \\
3(5)\end{array}$ & $\begin{array}{l}56 \\
8(14)\end{array}$ & $\begin{array}{l}12 \\
2(17)\end{array}$ & $\begin{array}{l}1 \\
1(100)\end{array}$ & $\begin{array}{l}69 \\
11(16)\end{array}$ & $\begin{array}{r}126 \\
14 \text { (11) }\end{array}$ \\
\hline $\begin{array}{l}\text { 3-6 months } \\
\text { Total No } \\
\text { No }(\%) \text { with } D / V\end{array}$ & $\begin{array}{l}44 \\
5\end{array}$ & 32 & $\begin{array}{l}34 \\
12(35)\end{array}$ & $\begin{array}{l}110 \\
18(16)\end{array}$ & $\begin{array}{l}4 \\
2(50)\end{array}$ & $\underline{0}$ & $\underline{0}$ & $\begin{array}{l}4 \\
2(50)\end{array}$ & $\begin{array}{r}124 \\
20(18)\end{array}$ \\
\hline $\begin{array}{l}6-9 \text { months } \\
\text { Total No } \\
\text { No }(\%) \text { with } D / V\end{array}$ & $\begin{array}{l}10 \\
2(20)\end{array}$ & $\begin{array}{r}43 \\
6(14)\end{array}$ & $\begin{array}{l}55 \\
8(15)\end{array}$ & $\begin{array}{l}108 \\
16(15)\end{array}$ & $\underline{0}$ & $\underline{0}$ & $\underline{0}$ & 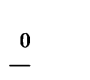 & $\begin{array}{l}108 \\
16(15)\end{array}$ \\
\hline $\begin{array}{l}9-12 \text { months } \\
\text { Total No } \\
\text { No }(\%) \text { with } D / V\end{array}$ & $\stackrel{0}{-}$ & $\begin{array}{r}24 \\
8(33)\end{array}$ & $\begin{array}{l}71 \\
19(27)\end{array}$ & $\begin{array}{l}95 \\
27(28)\end{array}$ & $\underline{0}$ & $\underline{0}$ & 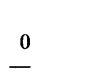 & $\underline{0}$ & $\begin{array}{l}95 \\
27(28)\end{array}$ \\
\hline
\end{tabular}


$\mathrm{D} / \mathrm{V}$ than those who received breast milk only or a combination of breast and bottle feeds. Infants who received both breast and bottle feeds had no more $\mathrm{D} / \mathrm{V}$ than those who received breast milk only. These findings indicate that, in the group studied, the absence of breast milk influenced the incidence of $\mathrm{D} / \mathrm{V}$ and the presence of other milks did not. Put another way, the protective effects of breast milk $^{2021}$ lowered any susceptibility to infection induced by other milks. After 6 months breast milk brought no significant protection against $\mathrm{D} / \mathrm{V}$. We still have no explanation for the significantly protective effect of solid food given in the first six months. The same observation was made in a similar study in Chile $^{22}$ but not in a study in New Zealand. ${ }^{3}$

These findings have practical implications for mothers and infants in a Western environment. Although $\mathrm{D} / \mathrm{V}$ is common, it is seldom severe, so the health penalties of bottle feeding are not great. If a mother wants to breast feed but cannot meet the needs of her infant, however, then this study shows that complementary bottle feeds do not increase the risk of $\mathrm{D} / \mathrm{V}$, while solid foods may lower the risk.

It would be potentially dangerous to extrapolate these findings uncritically to other countries and communities. In some developing countries where the nutrition of the mother and infant are poor mothers may traditionally, at an early age, supplement their breast milk with feeds of gruel, other milk, or foods. Such practices are perceived to maximise the benefits to the mother and the infant. The supplementation of breast milk with other foods may carry both high gains in nutrition and high risks of $D / V$ where environmental contamination is heavy. In this study giving supplementary foods to breast fed infants less than 6 months old did not increase the risk of $\mathrm{D} / \mathrm{V}$. There is a need to evaluate scientifically, in developing countries, the risks of $\mathrm{D} / \mathrm{V}$ against the benefits of such feeding practices in the maintenance of infants' health, including adequate nutritional state.

\section{Note}

Only summary tables of the data have been included in this paper. The Venn diagrams, which give the detailed data and have been used in the multifactorial analyses, are available from AED.

This study was funded by Wyeth Pharmaceuticals (Australia) Pty. We thank Dr P Livingstone, Director General, Queensland State Health Department, Dr J MacFarlane, former Director of the Division of Child Health, the staff of the division, and the nursing sisters at the maternal and child health clinics for their help in all aspects of this study. We also thank all the mothers who kindly participated in this study, came to the clinics each month, and answered all our many questions.

\section{References}

1 World Health Organisation. International code of marketing of breast milk substitutes. Geneva: WHO, 1981.

2 Cunningham AS. Morbidity in breast-fed and artificially fed infants. J Pediatr 1977;90:726-9.

${ }^{3}$ Fergusson DM, Horwood LJ, Shannon FT, Taylor B. Infant health and breast-feeding during the first 16 wecks of life. Aust Paediatr J 1978;14:254-8.

${ }^{4}$ Royal College of General Practioners. The influence of breast feeding on the incidence of infectious illness during the first year of life. Practitioner 1972:209:356-62.

5 Adebonojo FO. Artificial vs breast feeding. Clin Pediatr 1972;11:25-9.

${ }^{6}$ Gurwith M, Wenman W, Hinde D, et al. A prospective study of rotavirus infection in infants and young children. $J$ Infect Dis 1981;144:218-24.

${ }^{7}$ Fergusson DM, Horwood LJ, Shannon FT, Taylor B. Breastfeeding, gastrointestinal and lower respiratory illness in the first two years. Aust Paediatr J 1981;17:191-5.

${ }^{8}$ Saarinen UM. Prolonged breast feeding as a prophylaxis for recurrent otitis media. Acta Paediatr Scand 1982;71:567-71.

${ }^{9}$ Holmes GE, Hassanein KM, Miller HC. Factors associated with infections among breast-fed and babies fed proprietary milks. Pediatrics 1983;72:300-6.

${ }^{10}$ Sloper K, McKean L, Baum JD. Factors influencing breast feeding. Arch Dis Child 1975;50:165-70.

1 Kirk TR. Breast-feeding and mother's education. Lancet 1978;ii:1201-2.

12 Martinez GA, Nalezienski JP. 1980 update: the recent trend in breast-feeding. Pediatrics 1981;67:260-3.

13 Akroyd WR. Nutrition and mortality in infancy and early childhood: past and present relationships. Am J Clin Nutr 1971;24:480-7.

14 Waterlow JC, Thomson AM. Observations on the adequacy of breast milk. Lancet 1979;ii:238-42.

15 Anderson JAD, Gatherer A. Hygiene of infant-feeding utensils. Practices and standards in the home. Br Med J 1970;ii:20-3.

${ }^{16}$ Soderhjelm L. Infant feeding hygiene in Sweden. Acta Paediatr Scand 1972;61:565-70.

17 Congalton AA. Status and prestige in Australia. Melbourne: Cheshire, 1969.

${ }^{18}$ Cochran WG. Some methods for strengthening the common Chi-square tests. Biometrics 1954;10:417-51.

${ }^{19}$ Dugdale AE. A simple method of analysing multi-factoral data. Am J Clin Nutr 1975;28:788-92.

20) Welsh JK, May JT. Anti-infective properties of breast milk. J Pediatr 1979;94:1-9.

21 Goldman AS. Host resistance factors in human milk. J Pediatr 1973;82:1082-90.

22 Plank SJ, Milanesi ML. Infant feeding and infant mortality in rural Chile. Bull WHO 1973;48:203-10.

Correspondence to Dr A E Dugdale, Human Nutrition Research Group, Department of Child Health, University of Queensland, St Lucia, Queensland 4067, Australia.

Received 18 November 1986 